UDC 371.134

JEL Classification: K32

http://doi.org/10.21272/mmi.2018.4-06

Tadeusz Piatek,

D.Sc., Adjunct, Rzeszow University of Technology, Poland

\title{
WORK SAFETY MANAGEMENT - SOCIAL AND EDUCATIONAL CONTEXT
}

Abstract. The issue of security is a multithreaded issue. Most often, security is perceived as a state of no threats. In turn, Work Safety - a set of conditions that should be kept in the workplace, so that employees can perform their tasks safely and without harm to their own and others' health, also the lack of unacceptable risk of damage. The issues of security management can be considered in two contexts. The first is the social context - that is the role of health and safety services in creating a culture of safety, the culture of which the coverage is to include not only the workplace but the broadly understood human functioning in the general public sphere. The second context is the educational dimension related to the preparation of OHS services themselves, including the issue of selecting the content of education on educational forms (OHS technique, postgraduate studies in safety management) related to health and safety personnel as well as the selection of the training of employees themselves. On the one hand, these contents should result from relevant regulations, on the other hand, these contents should correspond to current health and safety challenges - that is, they should reflect real threats whose measurement and presentation of statements is dealt with, among others Central Statistical Office. From these lists, it is possible to read in which areas there are the highest risks of accidents at work and thus what to pay attention to when training employees. The article discusses selected aspects related to work safety management in the context of staff preparation for the implementation of work safety issues in work establishments (OHS services) and selected aspects of the work safety management process itself in workplaces and their socio-educational conditions aimed at changing employee attitudes in the area of responsibility for your and others' safety. The results of research related to the diagnosis of the safety culture are also presented. indirect way (analysis of its effects - the measure is the number of accidents or occupational diseases registered at a specific time); Direct method - (assessment of its constituent elements, that is the relation to the generally applicable and well-known rules of conduct, health and life values, applicable health and safety regulations, applicable standards). Qualitative methods: intelligence and intelligence, enhanced in terms of the effectiveness of the implemented $5 S$ and OS security management system in a large manufacturing company. The presented results clearly indicate a wide range of activities, covering not only the workplace but also the area of employees' private life.

Keywords: safety, work safety, management, education.

Introduction. The problem of occupational safety management can be seen from the perspective of methods and methods of operation of health and safety services, attitudes of employees in relation to workplace safety, or the education system for health and safety service workers implementing in practice work safety management in individual workplaces and employee training system.

The issue of occupational safety management is a complex problem that covers many scientific disciplines. In this theme, there are three basic thematic topics, such as work and safety at work and occupational safety management as (among others) a system of health and safety services.

The concept of work belongs to interdisciplinary concepts that function in the sciences related to both activities, human performance and action - machine operation efficiency. It should be noted that the operation of machines is conditioned by the phenomenon of converting energy obtained from the action of the elements, ie: fire, water, air, land in a direct or indirect way. We are talking about a job expressed, for example, in watts. It should be clearly emphasized that in this case the elements do not work, but they work and, as previously mentioned, the effect of their operation is "machine work".

Human work - human work is generally understood as a human activity consisting in transforming natural assets and adapting them to meet human needs. The effect of work is the creation of material

Cite as: Piatek, T. (2018). Work Safety Management - Social and Educational Context. Marketing and Management of Innovations, 4, 66-72. 
goods, cultural and social values of significant services that usually have an economic dimension. Relatively often, human work is perceived as a source of income (money) necessary for functioning in society, but also income that is an indicator of the level - quality of life of a person, an indicator of the possibility of occurrence of dangers related to lowering this standard of living. Perceiving work only from the perspective of a source often leads to unfavourable attitudes of employees in the field of occupational safety, that is behaviour that threatens them or conducts threatening the safety of others.

Work from the axiological point of view is a good fairness, it corresponds to human dignity, and this dignity is expressed in the content, processes and results of work. This involves the entire syndrome of values, and in its freedom, responsibility for oneself and others, and others. The relationship between these values as a conscious subject of work should be clearly understood. Because only then will the deep sense of work be revealed and only in such a situation it will be possible to enter this form of human activity into the content of human life in the sense of human life.

The concept of safety is also understood in many ways, in many aspects (Bera 2018; Kunikowski 2015; Siemiątkowski, 2017). Most often, safety is associated with a lack of threats. Security is a condition for optimal human functioning, both in the national and international dimension. Providing the desired level of security enables people to undertake any activity, free development or survival. Safety is a positive state that does not occur independently, but it should be considered in the context of a specific subject or subject of protective measures (Oleksiewicz, Jurgielewicz 2015).

As noted by J. L. Illanes - work from Latin. labour means effort, hardship, fatigue, and work in the sense in which work requires effort and causes or can cause fatigue. The word retains this meaning and, to a greater or lesser extent, these shades in the various modern languages to which he passed: lavoro in Italian, labour in English, labour in Spanish, and so on. Among the derivative words, some, like the adjective "laborioso" (industrious) and adverb "laboriosamente" (laboriously) include and emphasize the reference to effort and effort because they are applied to activities that are accomplished only through a difficult and non-fatigue effort (Illanes 2018).

Understanding work as an effort, effort imposes a way of looking at human work as an activity in which the body fatigue process occurs and thus a greater possibility of occurrence of various types of threats, hence the necessity of activities related to the occupational safety management system.

Occupational safety management - social aspect. Human work is of a social nature, despite its individual implementation, because almost everything that man produces is the result of cooperation between people, for example by using the results of other people's work in a new job and tasks (Bańka 1983).

One of the most important issues in the field of broadly understood security seems to be social security - understood as protection of the existential basis of human life, ensuring the ability to meet individual needs (material and spiritual) and pursuing life aspirations by creating conditions for work and study, health protection and guarantees retirement. As noted by U. Soler (Soler 2016), social security is usually defined as the whole of the institutions that are or should be established in order to provide security while taking into account the specific needs of people. Security through the prism of these institutions covers all legal, organizational and educational activities carried out by the government (national and supranational), nongovernmental entities and citizens themselves, which aim at providing a certain standard of living for individuals, families, social groups and preventing marginalization and social exclusion.

The social aspect of work should also be considered from the point of view of the prestige of the social work of a given person, namely the prestige associated with the profession or the lack of prestige associated with having the status of an unemployed person. 
Table 1 - Persons injured in accidents at work a by absenteeism resulting from accidents at work in 2017

\begin{tabular}{|c|c|c|c|c|c|c|c|c|c|}
\hline \multirow[b]{2}{*}{ Specification } & \multirow[b]{2}{*}{ Total } & \multicolumn{8}{|c|}{$\begin{array}{l}\text { Persons injured in accidents at work by absenteeism resulting from accidents at } \\
\text { work in } 2017\end{array}$} \\
\hline & & $\begin{array}{c}0 \\
\text { Days }\end{array}$ & $\begin{array}{l}1-3 \\
\text { Days }\end{array}$ & $\begin{array}{l}4-13 \\
\text { Days }\end{array}$ & $\begin{array}{l}14-20 \\
\text { Days }\end{array}$ & $\begin{array}{l}21 \text { days } \\
1 \text { month }\end{array}$ & $\begin{array}{c}1- \\
3 \text { months }\end{array}$ & $\begin{array}{l}3- \\
6 \text { months }\end{array}$ & $\begin{array}{c}6 \\
\text { months } \\
\text { and } \\
\text { more }\end{array}$ \\
\hline TOTAL & 88330 & 2322 & 1592 & 18279 & 13910 & 14363 & 25530 & 8421 & 3913 \\
\hline $\begin{array}{l}\text { of which in fatal } \\
\text { accidents }\end{array}$ & 270 & 236 & 6 & 11 & 4 & 1 & 10 & 2 & - \\
\hline $\begin{array}{l}\text { Agriculture, forestry and } \\
\text { fishing }\end{array}$ & 1323 & 27 & 11 & 218 & 172 & 215 & 432 & 144 & 104 \\
\hline of which agriculture & 859 & 6 & 6 & 122 & 108 & 155 & 302 & 96 & 64 \\
\hline Mining and quarrying & 2200 & 27 & 2 & 130 & 139 & 250 & 819 & 570 & 263 \\
\hline $\begin{array}{l}\text { of which mining of hard } \\
\text { coal }\end{array}$ & 1317 & 17 & - & 36 & 56 & 110 & 511 & 410 & 177 \\
\hline Manufacturing & 29057 & 295 & 449 & 5992 & 4789 & 4713 & 8808 & 2731 & 1280 \\
\hline $\begin{array}{l}\text { Electricity, gas, steam } \\
\text { and }\end{array}$ & 707 & 13 & 13 & 87 & 81 & 117 & 236 & 112 & 48 \\
\hline $\begin{array}{ll}\text { Water } & \text { supply; } \\
\text { sewerage } & \end{array}$ & 2527 & 35 & 43 & 465 & 407 & 446 & 774 & 261 & 96 \\
\hline Construction & 5390 & 111 & 77 & 747 & 727 & 781 & 1826 & 706 & 415 \\
\hline $\begin{array}{l}\text { Trade; repair of motor } \\
\text { vehicles }\end{array}$ & 11816 & 246 & 217 & 2867 & 2110 & 1976 & 3144 & 856 & 400 \\
\hline $\begin{array}{l}\text { Transportation and } \\
\text { storage }\end{array}$ & 6949 & 172 & 114 & 1379 & 1022 & 1114 & 2034 & 775 & 339 \\
\hline $\begin{array}{l}\text { Accommodation and } \\
\text { catering }\end{array}$ & 1313 & 14 & 30 & 399 & 250 & 210 & 304 & 65 & 41 \\
\hline $\begin{array}{l}\text { Information and } \\
\text { communication }\end{array}$ & 471 & 22 & 32 & 106 & 66 & 66 & 133 & 32 & 14 \\
\hline $\begin{array}{l}\text { Financial and insurance } \\
\text { activities. }\end{array}$ & 1068 & 112 & 25 & 250 & 149 & 163 & 258 & 77 & 34 \\
\hline Real estate activities & 943 & 22 & 14 & 179 & 155 & 146 & 257 & 118 & 52 \\
\hline $\begin{array}{l}\text { Professional, scientific } \\
\text { and technical activities }\end{array}$ & 1201 & 55 & 37 & 278 & 206 & 189 & 317 & 78 & 41 \\
\hline $\begin{array}{lr}\text { Administrative } & \text { and } \\
\text { support } & \text { service } \\
\text { activities } & \\
\end{array}$ & 4009 & 98 & 95 & 931 & 626 & 625 & 1193 & 308 & 133 \\
\hline $\begin{array}{lr}\text { Public administration } \\
\text { and } & \text { defence; } \\
\text { compulsory } & \text { social } \\
\text { security } & \\
\end{array}$ & 4091 & 247 & 135 & 923 & 568 & 642 & 1065 & 374 & 137 \\
\hline Education & 4609 & 302 & 122 & 995 & 681 & 735 & 1203 & 393 & 178 \\
\hline $\begin{array}{l}\text { Human health and } \\
\text { social work activities }\end{array}$ & 9337 & 421 & 150 & 2083 & 1541 & 1806 & 2363 & 705 & 268 \\
\hline $\begin{array}{l}\text { Arts, entertainment and } \\
\text { recreation }\end{array}$ & 881 & 96 & 21 & 162 & 143 & 111 & 232 & 80 & 36 \\
\hline Other service activities & 438 & 7 & 5 & 88 & 78 & 58 & 132 & 36 & 34 \\
\hline
\end{tabular}

Sources: GUS 2017 
In research, where the social dimension of the profession, professional and life aspirations are analyzed, work is most often perceived as a source of income as a way to ensure safety for the family and for themselves. The social aspect of work has a dimension of realizing human needs, from physiological needs to the needs of self-realization (Piątek 2013; Opar, Piątek 2015), but it can also play an important role in the process of socialization and resocialization. The social aspect of work safety also means actions of the state in order to restore people who have suffered an accident to normal functioning. The social dimension of human work safety is the costs that society must incur for various types of compensation and redundancy days.

Work safety - a set of conditions that should be kept in the workplace so that employees can perform their tasks safely and without harm to health. To a large extent, it depends on the training and conduct of employees.

Safety at work in workplaces in Poland is supervised by the National Labor Inspectorate (CIOP, 2018).

The labour protection system in Poland consists of:

- the system of legal remedies;

- $\quad$ the system of economic resources (credit: customs; tax);'

- $\quad$ the system of technical means (standardization; testing system and certification);

- the system of organizational means (education; science; health insurance; social insurance (GUS, 2017).

From the viewpoint of the system of organizational means includes education and science. The educational dimension of safety management consists of the following elements:

- training of health and safety services;

- training of employees as part of health and safety services;

- training of employees as part of the Quality Management System (5S) (Misiurek, 2018).

Training of health and safety services. Education is a necessary condition resulting from the applicable legal provisions.

Pursuant to $\S 4$ Regulation of the Council of Ministers of November 2, 2004, amending the Regulation on health and safety at work (paragraph 1), the career path of an occupational health and safety worker is five-grade. He can work as the main specialist, senior specialist, specialist, senior inspector, inspector. Employment at individual positions depends on your education and seniority.

Postgraduate studies in the field of occupational health and safety should ensure preparation of graduates to perform the tasks of health and safety service, and hence - their scope should take into account the topics that enable such preparation. Therefore, the content of the education program is of decisive importance in case of doubts whether the given studies give sufficient qualifications to practice.

At present, in Poland, OHS service workers are educating many post-secondary schools, universities and institutes offering post-graduate programs to their students. There are also universities that create interdisciplinary engineering studies preparing for work in health and safety services, giving their graduates the titles of engineers in the field of health and safety.

Pursuant to $\S 4$ Regulation of the Council of Ministers of November 2, 2004, amending the Regulation on health and safety at work (paragraph 2) HSE employees may be persons meeting the following eligibility requirements:

1) the inspector for occupational health and safety may be a person who is a technician of occupational safety and hygiene;

2) a senior inspector for occupational health and safety may be a person who has:

3) occupation as a health and safety technician and at least 3 years' service in the service of health and safety or

4) university degree in specializations or specialities in the field of occupational health and safety or post-graduate studies in the field of occupational health and safety; 
5) a specialist for occupational health and safety may be a person with higher education in a field or speciality in the field of occupational health and safety or postgraduate studies in the field of occupational health and safety and at least 1 year of service in the health and safety service;

6) a senior specialist for occupational safety and health may be a person with higher education about a specialization or speciality in the field of occupational health and safety or postgraduate studies in the field of occupational health and safety and at least 3 years of service in the health and safety service;

7) the main specialist for occupational health and safety may be a person with higher education about the field of study or speciality in the field of occupational health and safety or postgraduate studies in the field of occupational health and safety and at least 5 years of work experience in the health and safety service.

An employee with higher education has the opportunity not only to direct a multi-person organizational unit for occupational health and safety - $\S 4$ Regulation of the Council of Ministers of November 2, 2004 amending the Regulation on health and safety at work (paragraph 3), but also running your own business, i.e. providing health and safety services for enterprises, as part of entrusting the performance of tasks of the OHS service to specialists from outside the workplace - $\S 4$ Regulation of the Council of Ministers of November 2, 2004 amending the Regulation on health and safety at work (paragraph 2) (MGiP, 2004; MPiPS, 2010; RM ,1997).

One of the most important tasks of both health and safety services and other specialized cells in the workplace, eg the quality department, is training in both the organization of work and issues related to the most common cause of accidents.

Own research in the field of the socio-educational dimension of safety management. The tests were carried out from a large furniture manufacturing plant. The company's headquarters is located in Poland. In addition, the plant has branches of the company both in Poland and abroad. The company has implemented a 6S management system.

As part of the adopted research procedure, quantitative and qualitative methods were applied. As part of the quantitative methods, the source documents regarding accidents at work on a national scale were analyzed (table 1).

Qualitative research serves to interpret emotions and deeply hidden motives of action. They allow the identification of specific behaviours, show patterns of thinking, behaviour, habits and rules of action. They allow getting to know the hidden motives of actions and choices. Within the quality methods, an interview and an in-depth interview were used. In these interviews, persons responsible for the implementation of the $6 \mathrm{~S}$ system (training department, foremen, managers) were asked about the answer (among others) how the implementation of the said system affected work safety, compliance with work safety standards, on work efficiency and what was the decisive factor about increasing the quality of work safety in the plant.

The research group consisted of employees of the training department and managers of production teams. In the light of the results of qualitative research, the decisive factor increasing work safety in both the point of compliance with health and safety standards and awareness of hazards and consequences of accidents was education carried out in a permanent way. Apart from periodic health and safety training, employees were trained in work efficiency. The result of these training, as well as consistency in working for work safety, were visible outside the workplace, where employees declared that they use occupational health and safety measures in non-professional, domestic situations, etc. The habit of using protection measures in the workplace - he was transferred to everyday life. In conclusion, it can be stated that training in labour law - the labour code as part of periodic training and training in the field of typical and unusual hazards at a given workstation, work-room is the key to increasing the safety culture both in the dimension of awareness and real attitudes.

Conclusions. Summary Managing work safety in a socio-educational context is a complex multithreaded issue. In the conducted qualitative research, the purpose of which was to check to what extent 
the implementation of the safety management system affected the safety and security of employees - in light of the statements of the management of the plant education in this area was a decisive factor in the correct attitudes and behaviors in the field of occupational health and safety beyond him. These statements were confirmed by the observation of the employees' behaviour on the production hall and their statements - confirmation that they apply measures to protect health and safety from, among other things, habits, but also from the awareness of hazards and health consequences. The second aspect of the subject of the article was related to the training in the management of occupational safety and hygiene. The dominant elements of education were: provisions of the Labor Code, analysis of occupational risk, the methodology for conducting health and safety training, first aid. It should be noted here that the "Labor Code" - a normative act constituting a set of provisions regulating the rights and obligations in force in Poland (the Act of 26 June 1974) is the most frequently amended Act. Hence, the conclusion that in the framework of the training of health and safety services within the scope of the provisions of the Labor Code the most important is the ability to self-education and professional self-improvement.

\section{References}

Banka, J. (1983). Ja teraz. U zrodel filozofii czlowieka wspolczesnego, Katowice.

Bera, R. (2017). Pedagogika bezpieczenstwa w kontekście wspolczesnych zagrozen w zyciu spolecznym, Annales Universitatis Mariaecurie - Sklodowska Lublin - Polonia Vol. XXX, 4 Sectioj 2017;

EWG (1989). Dyrektywa Rady 89/391/EWG z dnia 12 czerwca 1989 r. w sprawie wprowadzenia środkow w celu poprawy bezpieczenstwa i zdrowia pracownikow w miejscu pracy (tzw. dyrektywa ramowa). Available: https://eurlex.europa.eu/LexUriServ/LexUriServ.do?uri=CONSLEG: 1989L0391:20081211:PL:PDF

GUS (2017). Wypadki przy pracy, pobrano z http://stat.gov.pl/obszary-tematyczne/rynek-pracy/warunki-pracy-wypadki-przypracy/wypadki-przy-pracy-w-2017-roku,4,11.htm I

CIOP (2018). System ochrony pracy w Polsce. Avaivalble: http://www.CIOP.pl

PIP (2018). Avaivalble: http://www.PIP.gov.pl

Misiurek B., (2018). System 5S czy system 6S? Available: https://leantrix.com/pl/system-5s-system-6s/

Illanes. J. L. (2009). Pracowitość, porządek. Available: https://opusdei.org/pl-pl/article/30-pracowitosc-porzadek/

Kunikowski J. (2015), Slownik terminow wiedzy i edukacji dla bezpieczenstwa, wyd. IV - rozszerzone, Siedlce 2015.

Kodeks pracy (2018). Available: https://leantrix.com/pl/system-5s-system-6s/

Oleksiewicz l., Jurgielewicz O. (2015). Rola i znaczenie panstwa jako gwaranta bezpieczenstwa obywateli. Rzeszow 2015.

Opar A., Piątek T. (2015). Wartości i normy w procesie resocjalizacji i socjalizacji, (w:) Wartości w pedagogice. Rodzina i szkola środowiskami urzeczywistniania wartości, red. W. Furmanek, A. Dlugosz, Rzeszow, s. 214-223.

Piatek T. (2013). Ergonomia i bezpieczenstwo prac, Rzeszow 2013.

MGiP (2004). Rozporządzenie Ministra Gospodarki i Pracy z dnia 27 lipca 2004 r. w sprawie szkolenia w dziedzinie bezpieczenstwa i higieny pracy (Dz.U. z 2004 r, nr 180, poz.1860 z pozn. zm.) Available: http://prawo.sejm.gov.pl/isap.nsf/

MPiPS (2004). Rozporządzenie Ministra Pracy i Polityki Spolecznej z dnia 27 kwietnia 2010 r. w sprawie klasyfikacji zawodow i specjalności na potrzeby rynku pracy oraz zakresu jej stosowania, $\mathrm{Nr}$ 82, poz. 537. Available: http://prawo.sejm “.gov.pl/isap.nsf/

RM (1997). Rozporządzenie Rady Ministrow z 2 września 1997 r. w sprawie sluzby bezpieczenstwa i higieny pracy (Dz. U. Nr 109, poz. 704 z pozn. zm.). Available: http://prawo.sejm.gov.pl/isap.nsf/

RM (2004). Rozporządzenie Rady Ministrow z dnia 2 listopada 2004 r. zmieniające Rozporządzenie w sprawie sluzby bezpieczenstwa i higieny pracy (Dz.U. z 2004 r. nr 246, poz.2467 i 2468). Available: http://prawo.sejm.gov.pl/isap.nsf/

Siemiatkowski, P. (2017). External financial security of the European Union member states outside the Eurozone. Journal of International Studies, 10(1), 84-95. doi:10.14254/2071-8330.2017/10-4/6

Soler U. (2016). Bezpieczenstwo spoleczne versus Internet: jaka przyszlość? [w:] Oleksiewicz I., Stępien K., (red.), Zagrozenia i wyzwania bezpieczenstwa wspolczesnego świata. Wymiar ekonomiczno - spoleczny. Warszawa.

T. П'ятек, D.Sc., ад'юнкт, Ржешовський технологічний університет (Польща).

Управління безпекою праці - соціальний та освітній контекст

У статті автор визначає, що дослідження питань безпеки вимагає використання міждисциплінарних підходів. Традиційно безпеку розглядають як стан, при якому будь-які загрози відсутні. У свою чергу у статті автор визначає безпеку праці як формування відповідних умов праці на робочому місці, що гарантують належні та безпечні умови роботи. Так, автор розглядає питання управління безпекою з двох точок зору. По-перше, з соціальної точки зору - місце та вплив стану здоров'я працівників у створенні культури безпеки, яка включає не лише безпеку на робочому місці, але й безпеку поведінки 
працівника у суспільстві. По-друге, з освітньої точки зору - розробка та надання освітніх послуг з охорони праці, у тому числі вибір змісту та форм освітнього процесу (технічна допомога з охорони праці, освітні програми з управління безпекою) при підготовці фахівців з охорони здоров'я та безпеки, а також розробка системи забезпечення самостійного навчання впродовж життя. 3 одного боку, зміст освітніх програм повинен грунтуватись на відповідних нормативно-правових актах та регламентах, а з іншого боку, ці освітні програми повинні відповідати сучасним проблемам у галузі охорони здоров'я та безпеки. Тобто, вони повинні бути побудовані на реальних практичних знаннях та прикладах, які $\epsilon$ вимірюваними та обліковуються Центральним Статистичним управлінням. Автор, наголошує, що аналіз статистичних даних щодо кількості нещасних випадків дає підстави виокремити найризикованіші умови праці та сконцентрувати програму підготовку на вузьких місцях при підготовці фахівців у галузі безпеки праці. у статті розглядаються специфіка управління безпекою праці в контексті підготовки персоналу у галузі охорони і безпеки праці у відповідних структурах (служби охорони праці) та окремі аспекти процесу управління безпекою праці на робочих місцях, з метою посилення ролі та відповідальності працівника за власну безпеку та оточуючих. У рамках дослідження для діагностики культури безпеки автор використовує наступні методи: прямий (аналіз наслідків - оцінка - кількість випадків або професійних захворювань, зареєстрованих у певний час); непрямий (оцінка основних складових елементів, тобто відношення до загальноприйнятих та відомих правил поведінки, здоров'я та життєвих цінностей, правил охорони здоров'я та техніки безпеки); якісний - рівень освіти, з точки зору критеріїв оцінки програм управління безпекою $5 S$ та OS у компаніях.

Ключові слова: безпека, безпека праці, управління, освіта.

Manuscript received: 16.10.2018

(C) The author(s) 2018. This article is published with open access at Sumy State University. 